Sandra Ateljević

UDC 81'246

Faculty of Humanities

Eötvös Loránd University

$811.511 .141: 81^{\prime} 23$

DOI https://doi.org/10.18485/fid.2017.7.ch22

\title{
HUNGARIAN MINORITY BILINGUALS AND MINORITY EDUCATION IN SERBIA
}

\begin{abstract}
У овом раду представљају се резултати квантитативног истраживања о мађарској мањини која је двојезична и њиховом образовању у хомогеној средини у Србији. Социолингвистичком анализом се истражује мишљење о образовању мањина у односу на језичку политику, језичко управљање и двојезичност. Истраживање је спроведено у општини Кањижа, која је претежно насељена мађарском националном групом. Циљ рада је се види како двојезичне особе припадници мађарске националне мањине оцењују свој образовни процес и да утврди да ли знање српског језика има било каквог утицаја националност. Ово мини истраживање показало је да српски језик, било као Л2 или Л1, нема негативан утицај на висок степен знања мађарског језика нити на стабилност националног идентитета код раних билингвала. Штавише, идентитет већине билингвала више је мађарски него српски и језички избор није нужно заснован на националном идентитету. Проширењем овог истраживања, прецизније образовне и социолингвистичке тенденције би се могле разликовати у хомогеним заједницама, што ће омогућити поновну процену језичких политика које ће фаворизовати окружење у коме се може развити адитивни билингвизам.
\end{abstract}

Кључне речи: адитивни билингвизам, рани билингвизам, мађарска мањина, језичка политика и планирање, националност, српски језик.

\section{Introduction}

Education has a key role in integrating minorities into the (majority) society and it serves as an important instrument for managing intercultural differences. Presently, Serbia offers three educational models to ethnic minorities, all of which are based on well-designed international legislation and implemented into the national legal framework of Serbia (Filipović, 2013). However, not all the models have been developed thoroughly and as a result minority members mostly choose to take part in the educational process in their L1 (model 1) or, alternatively, in Serbian as L2 and National language with elements of national culture (model 2). The bilingual education program (model 3) is also offered, but it is very rarely implemented. 
Whichever educational model is chosen, all of the minority members are in a way obligated to be bilingual. In its basic definition, bilingualism is the ability to understand and reproduce two languages. However, there exists no single agreed-upon definition of bilingualism and its variety is mostly caused by different understanding of how the two languages are used. Is a bilingual a person whose competencies in both languages are native-like? Is that person someone who acquired two languages during early childhood? Can a bilingual person be someone who uses one language proficiently and other less proficient? These kind of questions led researchers to try and classify bilingualism into several groups by the degree of fluency, level of competences, age, context or manner of acquisition and language representation.

For the purposes of this paper, bilingualism is going to be viewed as per Lambert's classification of bilingualism. Lambert distinguished bilingualism based on how one language influences the other. In case of additive bilingualism, both of the languages are developed equally and improving one language doesn't result in losing the proficiency in other. In case of subtractive bilingualism, learning L2 interferes with proficiency of their L1 (Hamzeh, 2014). We can also talk about subtractive bilingualism if a member of minority group loses proficiency of the L2 due to the dominance and overwhelming usage of L1. In this research I set to discover why early bilingual minority members make language preferences, how do they evaluate their language competencies in Serbian and Hungarian and is it anyway connected with their ethnic identity.

\section{Research}

In the municipality where this research was carried out, overwhelming majority of Hungarians have always chosen to complete the educational process in their native languages. Municipality of Kanjiža, which is located in the Northern Serbia, close to the border with Hungary, is predominantly populated with the Hungarian ethnic group. According to the latest Census of the population in 2011 , this municipality consists of $85 \%$ of Hungarians, $7 \%$ of Serbians and $2 \%$ of Roma. The statistics point out the obvious - the Hungarian national minority is in fact a majority in this municipality. This kind of homogenous environment is crucial for the native language development and also for the development of additive bilingualism. To my knowledge, no research about the bilingual competencies of the Hungarian-dominant com- 
munities has been undertaken so far, so no data exists on the real impact of the current language planning on the developing bilingualism of Hungarian minorities. This is the main reason why I have chosen early bilinguals as the target audience for this research. Early bilinguals are understood here as people who have acquired Serbian and Hungarian in their early childhood, before their enrollment in the formal education.

The aim of this research is to discover how Hungarian minority early bilinguals evaluate their educational process and to determine whether participating in educational process in Serbian as L1 has any effects on the national self-determination and native language preference.

\section{Methodological approach}

Quantitative approach is chosen for data collection. In order to appeal to a greater public I have used Google Forms to create a questionnaire which was offered in Serbian and Hungarian language separately. The questionnaire had 14 questions, which were mostly closed type questions, where the participants had to mark the level of agreement with a certain statement. The reason behind choosing this method was that it offers more accurate results, it is more appealing to the participants and the results are easier and faster to manage. However, these types of questions are lacking in the valuable, creative inputs and examples which can be provided by the participants if the questions would have been open-type ones. In the following text, due to publication's space limit I am going to present only a part of the results relevant to the subject.

In total, there were 45 random, anonymous participants in the research that evaluated themselves as early bilinguals (Serbian and Hungarian). The actual language competencies were not tested. There was approximately the same number of male and female participants and they were young people aged from 18 to 35 (most of them are between 26 and 30 years old).

Bilinguals who participated in this research are well educated. In total $71 \%$ holds a University or College degree, which is above the national average of Serbia (see Consensus of the Population of Serbia, 2011). Almost the same number of bilinguals completed their elementary and high school educational process in Serbian as in Hungarian. Naturally, at the University level that ratio changed as the majority of bilinguals continued their education in Serbian. Only 2 participants claimed to have been enrolled in a program on another language of instruction. 


\section{Results}

\subsection{Minority bilinguals and nationality preference}

4.1.1 The language choice. The results show that $62 \%$ of the bilinguals chose to fill in the questionnaire in Serbian language; this group of participants will be labeled as group A in the rest of the text, while 38\% chose Hungarian (group B). In Figure 1, a substantial difference between the results of group A and group B can be spotted. Group B preferred Hungarian language over Serbian while Group A had shown less straightforward answers and high level of uncertainty. In this group majority of the participants (33\%) did choose Serbian because they feel their competencies are higher than in Hungarian, however the second most frequent answer given was: "I don't know why I've chosen this language" (30\%). This is pointing out a very interesting tendency - that the language choice might not be necessarily based on national identity preference. Unequivocally, the participants see bilingualism as an asset, which helped them during their educational process, in their pursuit for a job, it also helped them in getting to know both of the cultures better etc. (please see Table 1) In other words, it helped them develop both self-awareness and awareness of other cultures.

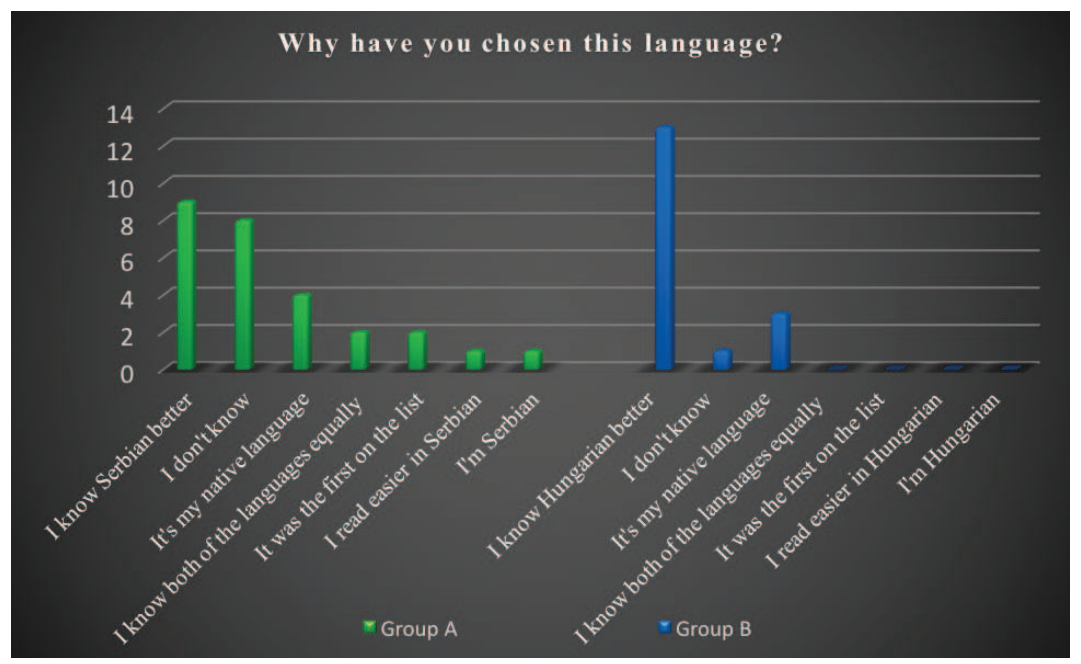

Figure SEQ Figure I* ARABIC 1: Language choice for the testing of the bilinguals Table 3 Opinion on bilingualism 
HUNGARIAN MINORITY BILINGUALS AND MINORITY EDUCATION IN SERBIA

\begin{tabular}{|c|c|c|c|c|c|}
\hline Statements & $\begin{array}{l}\text { I strongly } \\
\text { agree }\end{array}$ & $\begin{array}{c}\mathrm{I} \\
\text { agree }\end{array}$ & $\begin{array}{l}\text { Neither agree } \\
\text { or disagree }\end{array}$ & $\begin{array}{c}\mathrm{I} \\
\text { disagree }\end{array}$ & $\begin{array}{l}\text { I strongly } \\
\text { disagree }\end{array}$ \\
\hline $\begin{array}{l}\text { Bilingualism helped me in } \\
\text { getting to know Serbian } \\
\text { and Hungarian culture } \\
\text { better. }\end{array}$ & $47 \%$ & $36 \%$ & $7 \%$ & $0 \%$ & $11 \%$ \\
\hline $\begin{array}{l}\text { Bilingualism helped me in } \\
\text { my pursuit for a job. }\end{array}$ & $29 \%$ & $18 \%$ & $13 \%$ & $16 \%$ & $24 \%$ \\
\hline $\begin{array}{l}\text { Bilingualism helped me } \\
\text { during my education. }\end{array}$ & $33 \%$ & $24 \%$ & $26 \%$ & $7 \%$ & $10 \%$ \\
\hline $\begin{array}{l}\text { My school didn't take } \\
\text { enough effort in helping } \\
\text { me develop knowledge } \\
\text { equally in both of my } \\
\text { mother tongues. }\end{array}$ & $7 \%$ & $11 \%$ & $31 \%$ & $26 \%$ & $24 \%$ \\
\hline $\begin{array}{l}\text { Educational institutions in } \\
\text { Kanjiza Municipality offer } \\
\text { a high-quality education } \\
\text { for bilingual children. }\end{array}$ & $29 \%$ & $18 \%$ & $26 \%$ & $13 \%$ & $13 \%$ \\
\hline $\begin{array}{l}\text { It was a good decision to } \\
\text { complete my education in } \\
\text { Hungarian as L1. }\end{array}$ & $49 \%$ & $13 \%$ & $24 \%$ & $2 \%$ & $11 \%$ \\
\hline $\begin{array}{l}\text { It was a good decision to } \\
\text { complete my education in } \\
\text { Serbian as L1. }\end{array}$ & $53 \%$ & $22 \%$ & $16 \%$ & $2 \%$ & $7 \%$ \\
\hline
\end{tabular}

4.1.2 National identity preference. The top 2 bars in this graph show that the majority of the participants consider the identity preference important, but there is a significant difference between participants who filled in the questionnaire in Hungarian and the ones who filled the questionnaire in Serbian. The majority of bilinguals (82\%) who've chosen the Hungarian language questionnaire (Group B) consider themselves Hungarian (see the right bottom bar of the Figure 2) while $61 \%$ of participants who chose to fill in the Serbian questionnaire (Group A) feel they can identify with Serbian nationality (see the left bottom bar of the Figure2). However, participants from group A seem to be a bit more confused when their national identity is concerned. For example, the second bar on the left shows that $54 \%$ agrees that they are of both Serbian and Hungarian nationality. The 
reason behind such results might be due to the background of the participants' environment of language usage - it is unknown whether they are using both languages at home because their parents have different native languages, or if they have friends with different native languages etc. This variable should be taken into consideration further research.

To conclude, bilingual individuals who have experienced greater exposure to Hungarian as a language of instruction during compulsory education are more likely to say that they feel more Hungarian, while that same logic is not quite implacable in the case of individuals who have been exposed to Serbian as language of instruction probably because social environment as a factor has greater impact on the identity than the language of instruction in school. In other words, bilinguals who have been exposed to Serbian as language of instruction do not feel their nationality is more Serbian than Hungarian. Therefore, national culture of the majority in a certain (homogeneous) community plays a key role in building national or, in fact, any other kind of identity more than language of the education itself. In order to prove or disprove this tendency and establish the exact correlations between the language choice and national identity preferences this research should, naturally, be deepened and repeated.

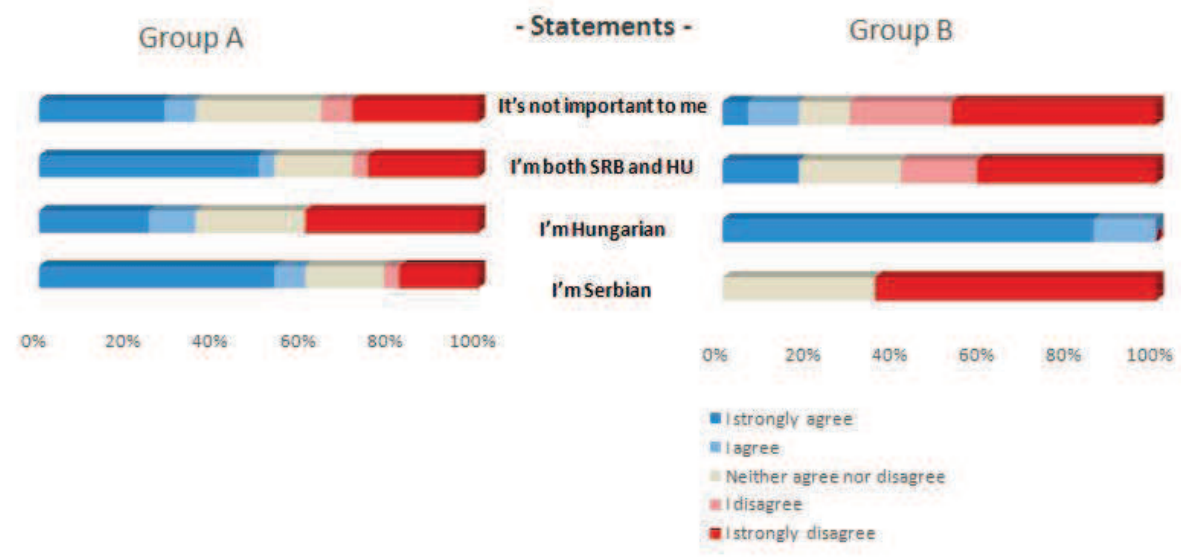

Figure SEQ Figure $I^{\star}$ ARABIC 2 National identity preferences of the bilinguals 


\section{Final remarks}

The implementation of bilingual model of education might be a good solution for homogeneous municipalities such as Kanjiza. According to Skutnabb (2000), good educational programmes should aim to achieve the following: a) high level of plurilingualism, b) positive outlook for progressing in school, c) building healthy and positive plurilingual and pluricultural attitudes towards the others and d) develop critical awareness and high intercultural competencies that lead to building a more equal cultural, ethnic and other communities. In that respect, bilingual education has many advantages. It helps students in developing competencies in foreign languages and (intercultural) communication. It creates a setting in which students can expand their creativity and their analytical capabilities. It facilitates the representation and exchange of information in the European context by intertwining educational system in Serbia and Europe through teachers and students exchange programs and professional visits in countries whose language they are learning or teaching. It is updating and modernizing the educational process. It promotes tolerance, multiculturalism, self-awareness and so much more (Vučo, 2014).

However, implementation of bilingual programs in Serbia started only from 2004/05 school year in a couple of elementary schools and high schools. The language combinations were mostly Serbian and one of the main foreign languages (French, Italian, German, Russian and English) and it had a strong support of foreign institutions and ministries. Bilingual program was based on a modified CLIL educational model (Vučo, 2014). Content and language integrated learning (CLIL) is a bilingual program which is based on content learning developed by Marsh and Maljersin 1997. This is the most widely used program in schools. In this program both of the languages are used as vehicular languages. The accent is on the language usage and communication, not on knowledge about the language. Language of instruction is not equally distributed. The usage of L2 is less than $50 \%$ unlike the existing Bilingual Immersion program, which offers $50 \%$ or more instruction time in L2. (Vučo, 2014) The curriculum created my Serbian Ministry of Education and Science hasn't changed in terms of

volume and criteria, only in terms of language of instruction (Vučo, 2014). 
In 2015, the autonomous province of Vojvodina (which has 6 official languages) started implementing Serbian-English bilingual education with the collaboration of the British Council. There are 4 preschools, 7 elementary schools and 3 high schools participating in the project. Elementary schools will implement the program from the $1^{\text {st }}$ and the $6^{\text {th }}$ grade. The English part of teaching follows the Cambridge International Primary Programme (from $1^{\text {st }}$ to $5^{\text {th }}$ grade) and the Cambridge Lower Secondary Programme (from $6^{\text {th }}$ to $8^{\text {th }}$ grade). The English part of teaching in high schools follows the IGCSE (International General Certificate of Secondary Education). All students are allowed to quit the programme and continue the classes in Serbian. The model is also based on CLIL according to which $30-45 \%$ of the total number of hours annually will be instructed in English.

According to Vučo (2014) there are still some issues which need to be improved like: teaching staff deficit, substantial financial support for teachers for attending additional courses, leveling down the (financial) dependency of schools from foreign institutions, managing the workload and setting the right indicators to achieve valid evaluation of dual programs.

Although bilingual programs in Serbian and other foreign languages are slowly developing and taking shape, and most importantly enjoying the support of relevant foreign institutions and broader public, the bilingual programs in Serbian and other minority languages are neglected and/or rejected. So far, there has been an attempt to introduce a SerbianBulgarian bilingual program (Filipović, 2009) and a Serbian-Bosnian programme but it has been unsuccessful. Moreover, the notion of introducing such programs is strongly opposed by minority councils, who claim it will only lead to language loss and complete assimilation. The only acceptable educational model from kindergarten to university is on native minority language (see for example Hungarian Minority Council's programme for Education). They have also expressed discontent with CLIL models, which can be justified. Filipović \& Vučo (2013) stated that bilingual educational model aggravates the selection of subjects to be taught in L2, because is not elaborated enough within Serbian educational legislature. However, Filipović \& Vučo (2013) suggested a solution - that teaching contents in L1 should remain in the areas which support and strengthen ethnic, cultural, religious and linguistic identity of the students like history, arts, music, etc. 
The lack of knowledge about bilingual programmes and bilingualism in general can lead to arbitrary and unscientific claims. In fairness, weak or poorly designed bilingual programs can lead to assimilation, but the tendencies that have been spotted as a result of this research have proven that even if the early bilingual minority members enroll in the educational process in Serbian, their native language skills in Hungarian and the national identity preference would not change. Knowledge of Serbian does not seem to have a negative impact on proficiency in Hungarian, regardless of the educational model the participant has been a part of or the stability of their national identity.

\section{References:}

Baker, C. (2006). Foundations of Bilingual Education and Bilingualism. Clevedon: Multilingual Matters.

Filipović, J. (2009). Moć reči: Ogledi iz kritičke sociolingvistike. Belgrade: Zadužbina Andrejević.

Filipović, J. (2011). Srpski kao jezik obrazovanja u obrazovanju nacionalnih manjina u Srbiji [Serbian as a language of education in the education of national minorities in Serbia]. In V. Krajišnik, Srpski kao strani jezik $u$ teoriji $i$ praksi. [Serbian as L2 in Theory and Teaching Practice] (pp. 351-364). Belgrade: Faculty of Philology. The Centre for Serbian as Foreign Language.

Filipović, J., Vučo, J., \& Đurić, L. (2007). Critical Review of Language Education Policies in Compulsory Primary and Secondary Education in Serbia. Current Issues in Language Planning, VIII (I).

Hamzeh, M. (2014). An Investigation through Different Types of Bilinguals and Bilingualism. International Journal of Humanities \& Social Science Studies (IJHSSS) , I (II), 107-112.

Hoffmann, C. (1999). An Introduction to Bilingualism. Essex: Pearson Education Limited.

Serbia, S. O. (2011). Consensus of the population; Book 1. Belgrade: Statistical Office of the Republic of Serbia.

Vučo, J. (2014). Dvojezična nastava stranih jezika u Srbiji. In J. Filipović, \& O. Durbaba, Jezici u obrazovanju i jezičke obrazovne politike. Belgrade: Faculty of Philology. 


\begin{abstract}
This paper presents results of quantitative research on the Hungarian minority bilinguals and their education in homogeneous settings in Serbia. The sociolinguistic analysis explores opinion about minority education in relation to language policies, language management and bilingualism. The research was conducted in the Municipality of Kanjiža, which is predominantly populated by the Hungarian national group. The aim of this paper is to observe how Hungarian minority group bilinguals evaluate their educational process and to determine whether knowledge of Serbian has any effects on nationality preference. This micro research has shown that Serbian, either as L2 and or as L1 does not seem to have a negative impact on proficiency in Hungarian or on the stability of the national identity of early bilinguals. Furthermore, the identity of the majority of bilinguals is more Hungarian than Serbian and the language choice is not necessarily based on national identity. By extending this research, more accurate educational and sociolinguistic tendencies could be distinguished in homogeneous communities, which will allow re-evaluation of language policies that will favour an environment in which additive bilingualism can develop.
\end{abstract}

Keywords: additive bilingualism, early bilingualism, Hungarian minority, language planning and policies, nationality, Serbian language.

\title{
Biographical statement
}

SANDRA ATELJEVIĆ was born and raised in Serbia. After high school, she graduated at the University of Belgrade, Faculty of Philology, Hungarian Language and Literature Programme. She was awarded a 1 year scholarship at Balassi Institute in Budapest to complete the Hungarology and Hungarian language Programme. She obtained her Master's Degree in Language, Literature and Culture at the University of Belgrade, Faculty of Philology. She is currently a second year PhD student enrolled in the Intercultural Linguistics Programme at the Eotvos Lorand University, Faculty of Humanities, Doctoral school of Linguistics. Her current research interests include mostly sociolinguistics topics, minority languages, bilingualism and intercultural communication. She lives and works in Budapest.

E-mail: sandra.ateljevic@btk.elte.hu 